\title{
GacS Sensor Domains Pertinent to the Regulation of Exoproduct Formation and to the Biocontrol Potential of Pseudomonas fluorescens CHAO
}

\author{
Sophie Zuber, Fiona Carruthers, Christoph Keel, Alexandre Mattart, Caroline Blumer, Gabriella Pessi, \\ Cécile Gigot-Bonnefoy, Ursula Schnider-Keel, Stephan Heeb, Cornelia Reimmann, and Dieter Haas
}

Laboratoire de Biologie Microbienne, Université de Lausanne, $\mathrm{CH}-1015$ Lausanne, Switzerland

Submitted 27 September 2002. Accepted 11 February 2003.

In the root-colonizing biocontrol strain CHA0 of Pseudomonas fluorescens, cell density-dependent synthesis of extracellular, plant-beneficial secondary metabolites and enzymes is positively regulated by the GacS/GacA two-component system. Mutational analysis of the GacS sensor kinase using improved single-copy vectors showed that inactivation of each of the three conserved phosphate acceptor sites caused an exoproduct null phenotype $\left(\mathrm{GacS}^{-}\right)$, whereas deletion of the periplasmic loop domain had no significant effect on the expression of exoproduct genes. Strain CHAO is known to synthesize a solvent-extractable extracellular signal that advances and enhances the expression of exoproduct genes during the transition from exponential to stationary growth phase when maximal exoproduct formation occurs. Mutational inactivation of either GacS or its cognate response regulator GacA abolished the strain's response to added signal. Deletion of the linker domain of the GacS sensor kinase caused signal-independent, strongly elevated expression of exoproduct genes at low cell densities. In contrast to the wild-type strain $\mathrm{CHA0}$, the gacS linker mutant and a gacS null mutant were unable to protect tomato plants from crown and root rot caused by Fusarium oxysporum f. sp. radicis-lycopersici in a soil-less microcosm, indicating that, at least in this plant-pathogen system, there is no advantage in using a signal-independent biocontrol strain.

Pseudomonas fluorescens CHA0 is a root-colonizing soil bacterium that protects a range of crop plants from diseases caused by fungal root pathogens (Haas et al. 2000; Keel and

Corresponding author: Cornelia Reimmann; Institut de Microbiologie Fondamentale, Université de Lausanne, CH-1015 Lausanne, Switzerland; E-mail: Cornelia.Reimmann@imf.unil.ch; Telephone: +41 2169256 32; Fax: +41216925635

Current address of Sophie Zuber: Department of Genetics, University of Melbourne, Victoria 3010, Australia.

Current address of Caroline Blumer: Functional Genomics, Aventis Pharma, Industriepark Hoechst, D-65926 Frankfurt am Main, Germany.

Current address of Gabriella Pessi: Center for Microbial Pathogenesis, University of Connecticut Health Center, Farmington CT 06030-3710, U.S.A.

Current address of Stephan Heeb: Institute of Infections and Immunity, University of Nottingham, Nottingham NG7 2RD, U.K.

Nucleotide and amino acid sequence data reported are available in the GenBank and EMBL databases under accession number AF246292.
Défago 1997; Voisard et al. 1994). This biological control is mediated to a considerable extent by antifungal secondary metabolites which are produced by strain $\mathrm{CHA} 0$ and certain other fluorescent pseudomonads under conditions of slow, nonexponential growth and high cell densities (Bloemberg and Lugtenberg 2001; Haas et al. 2000; Keel and Défago 1997; Pierson et al. 1998; Thomashow 1996; Walsh et al. 2001). Secondary metabolites of strain CHA0 mediating biological control include hydrogen cyanide (HCN), 2,4-diacetylphloroglucinol, and pyoluteorin (Haas et al. 2002; Keel and Défago 1997; Voisard et al. 1994). The production of these metabolites and some exoenzymes such as the AprA protease is positively regulated by the global activator GacA (Laville et al. 1992; Sacherer et al. 1994). GacA is the response regulator of a twocomponent regulatory system in which GacS (formerly LemA) serves as a membrane-bound sensor kinase (Bull et al. 2001; Chancey et al. 2002; Heeb and Haas 2001; Hrabak and Willis 1992; Rich et al. 1994; Sánchez-Contreras et al. 2002; Whistler et al. 1998).

The primary sequences of the GacS and GacA proteins are well conserved in many gram-negative bacteria. In a variety of animal- or plant-pathogenic strains, including Pseudomonas, Vibrio, Salmonella, Legionella, and Erwinia spp., mutational loss of GacS or GacA markedly attenuates the expression of certain virulence factors (Hammer et al. 2002; Heeb and Haas 2001). In strain CHA0 and other fluorescent pseudomonads, the GacS/GacA system is of central importance for biocontrol in that gacA mutants have lost the ability to protect a range of dicotyledonous plants from fungal root pathogens (Gaffney et al. 1994; Laville et al. 1992; Ligon et al. 1999; SchmidliSacherer et al. 1997). Sensor proteins similar to GacS also have been found in eukaryotes; they include the osmosensor SLN1 in yeast (Tao et al. 1999), regulators of hyphal formation in several fungi (Brinkman et al. 2001), and the ethylene receptor ETR1 in Arabidopsis (Bleecker et al. 1998).

A current model postulates that, in gram-negative bacteria, the GacS/GacA system upregulates the production of one or several small, noncoding regulatory RNA molecules (e.g., RsmZ; Fig. 1) which lift posttranscriptional repression exerted by a repressive complex formed at or near the ribosome binding site (RBS) of target genes. RsmA is believed to be a key component of this repressive complex (Blumer et al. 1999; Heeb and Haas 2001). This model is inspired by the finding that, in enteric bacteria, the RsmA protein (=CsrA) can be sequestered by the regulatory RNA RsmB (=CsrB), whereby the negative effect of RsmA is relieved (Baker et al. 2002; Romeo 1998). In Escherichia coli and the plant pathogen Erwinia carotovora, homologs of the GacS/GacA system positively 
control the expression of RsmB (CsrB) (Cui et al. 2001; Hyytiäinen et al. 2001; Suzuki et al. 2002). Furthermore, Altier and associates (2000) have demonstrated that, in Salmonella typhimurium, a barA (gacS) mutation can be suppressed by overexpression of a regulatory RNA homologous to CsrB of Escherichia coli. In P. fluorescens strains F113 and CHA0, the small regulatory RNAs PrrB and RsmZ, respectively, are positively controlled by GacA and, when overexpressed, can phenotypically suppress a gacA mutation (Aarons et al. 2000; Heeb et al. 2002).

GacS has two transmembrane segments and consists of three putative phosphotransfer domains: a transmitter, a receiver, and a C-terminal secondary transmitter (termed Hpt for histidine phosphotransfer) (Heeb and Haas 2001). By analogy with other unorthodox sensor kinases (Kwon et al. 2000; Perraud et al. 1999; Uhl and Miller 1996), it can be hypothesized that a phosphorelay mechanism operates in GacS, whereby the conserved amino acid residues His-294 in the transmitter, Asp-717 in the receiver, and His-863 in the Hpt domain, in this order, would be phosphorylated (Fig. 1). Phosphotransfer then occurs from GacS to GacA. This has been demonstrated in vitro for the GacS/GacA homologs BarA/UvrY of E. coli (Pernestig et al. 2001). Phosphorylated GacA is assumed to be the transcriptional activator of the signal transduction pathway controlling exoproduct formation. Several sensor kinases are known to interact in their periplasmic domain with signal molecules (Galperin et al. 2001). Another sensor domain that can be important for signal perception and transduction is the linker domain (Williams and Stewart 1999), which is located between the second transmembrane segment and the transmitter (Fig. 1). Upon interaction with an activating signal, sensor kinases undergo conformational changes favoring autophosphorylation (Williams and Stewart 1999). There is evidence that culture supernatants of dense $P$. fluorescens $\mathrm{CHA} 0$ cultures contain a low molecular weight signal molecule that stimulates the expression of the GacA regulon, in particular by activating the transcription of the $r s m Z$ gene (Heeb et al. 2002). This signal, which has not yet been identified chemically, is not related to quorum-sensing signals of the $\mathrm{N}$-acylhomoserine-lactone (AHL) type (Heeb et al. 2002), and it is not known where in the GacS/GacA signal transduction pathway this molecule interacts.

The aim of this study using $P$. fluorescens $\mathrm{CHA} 0$ as a model is to investigate the roles of various GacS domains (Fig. 1) in the activation of the GacA regulon specifying exoproduct synthesis. In particular, we present evidence for a signal-blind gacS mutant that expresses exoproduct genes at low cell densities irrespective of the presence of the signal. We then tested the biocontrol properties of this mutant in a microcosm with tomato and Fusarium oxysporum $\mathrm{f}$. sp. radicis-lycopersici as a pathogen, to see if this gacS mutation would lead to improved plant protection.

\section{RESULTS}

\section{Essential conserved amino acid residues in the sensor kinase GacS.}

Phosphotransfer from the GacS homolog BarA to the GacA homolog UvrY has been demonstrated in E. coli (Pernestig et al. 2001), but the amino acid residues of GacS involved in phosphotransfer have not been determined experimentally. The GacS model (Fig. 1) predicts that His-294 is the site of autophosphorylation and that Asp-717 and His-863 are involved in phosphotransfer, by analogy, e.g., with the ArcB sensor of $E$. coli (Kwon et al. 2000). Point mutations were introduced into the gacS gene of P. fluorescens CHA0, creating either a His294 to Arg, an Asp-717 to Asn, or a His-863 to Arg change (discussed below). These alleles as well as the ac $^{+}$wild-type gene were integrated as single copies into the $P$. fluorescens chromosome of a mutant deleted for gacS, resulting in strains CHA19.3 [gacS(H294R)], CHA19.4 [gacS(D717N)], CHA19.5 [ $g a c S(H 863 R)]$, and CHA19.1 $\left(\right.$ gac $\left.^{+}\right)$, respectively. All three mutants had a gacS null phenotype (i.e., they did not produce detectable amounts of $\mathrm{HCN}$, AprA protease, 2,4diacetylphloroglucinol, and tryptophan side chain oxidase) (data not shown). By contrast, the reconstructed gacS $^{+}$strain CHA19.1 was indistinguishable from the wild-type CHA0. Thus, a phosphorelay typical of tripartite unorthodox sensor kinases (Perraud et al. 1999) is likely to operate in GacS.

\section{GacS and GacA are essential \\ for transduction of an extracellular inducing signal.}

We have shown previously that supernatants of CHA0 cultures grown to high cell density contain a solvent-extractable signal that activates the transcription of the $r \sin Z$ gene and, hence, increases the posttranscriptional expression of exoproduct genes such as hcnA (for HCN synthase) (Heeb et al. 2002). We verified that this signal requires a functional GacS/GacA system to bring about the activation of a translational hcnA'-lacZ reporter fusion carried by the plasmid pME3219 (Blumer et al. 1999). In the wild-type CHA0, the addition of signal stimulated the expression of the reporter twoto threefold (Fig. 2A), whereas in the gacS deletion mutant CHA19, the signal had no significant effect on the low-level expression of the reporter (Fig. 2B). Interestingly, the $\operatorname{gac} S(\Delta 128)$ mutant CHA19.6 deleted for codons 34 to 161 ap-

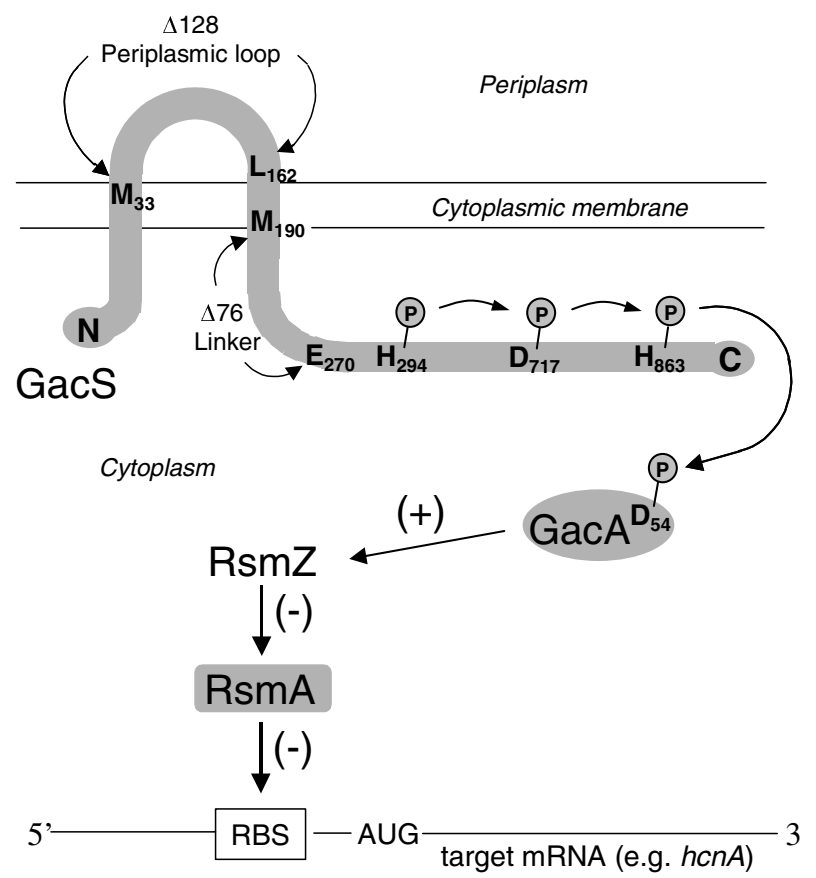

Fig. 1. Model of the GacS/GacA signal transduction pathway in Pseudomonas fluorescens. The postulated phosphorelay indicated by $\mathrm{P}$ and arrows is based on a comparison with the other two-component systems involving a tripartite sensor kinase (e.g., ArcB/ArcA in Escherichia coli) and is supported by the in vitro demonstration of phosphotransfer from BarA (GacS) to UvrY (GacA) in E. coli (Kwon et al. 2000; Pernestig et al. 2001; Perraud et al. 1999) as well as by the mutational analysis performed in this study. Accordingly, GacS is assumed to be autophosphorylated at His-294. The phosphate then could be transferred to Asp-717 in the receiver domain and to His-863 in the Hpt domain of GacS and, ultimately, to Asp-54 in the receiver domain of GacA. RsmZ, regulatory RNA similar to PrrB (Aarons et al. 2000; Heeb et al. 2002); RsmA, RNA binding protein (Blumer et al. 1999); (+) postulated positive control; (-) postulated negative control. 


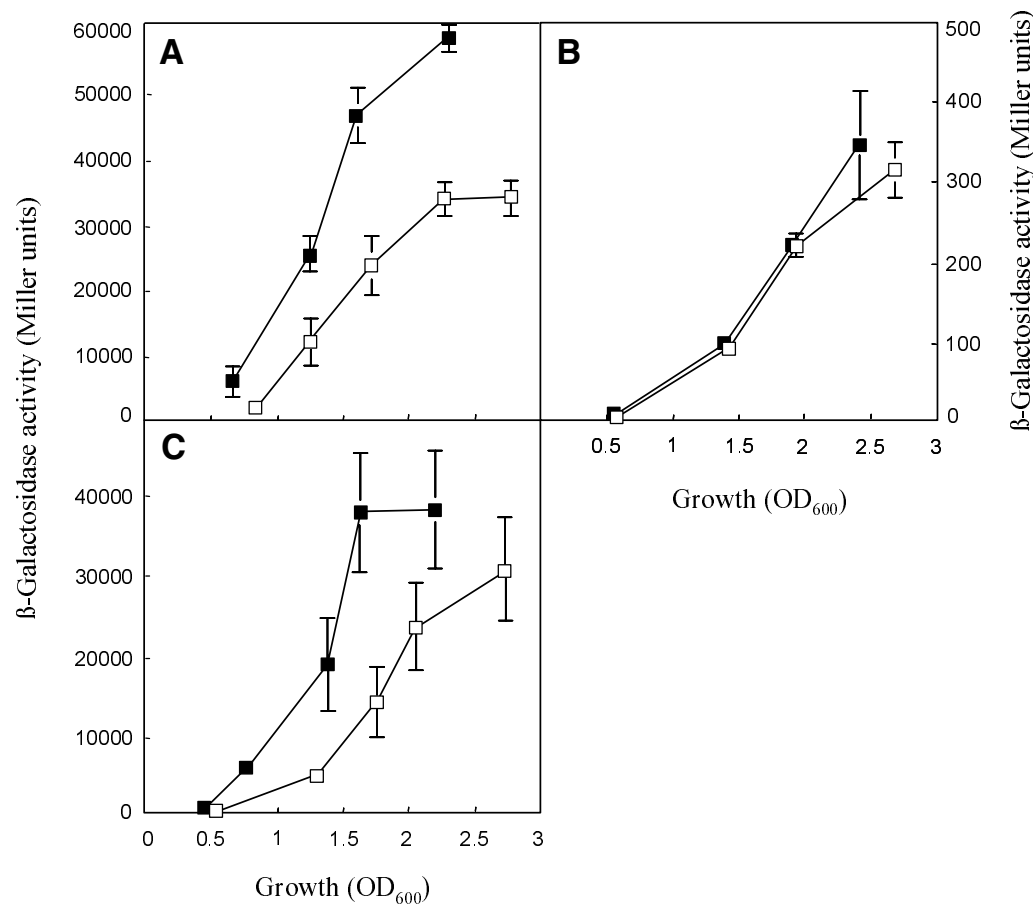

Fig. 2. GacS is required for induction of $h c n A^{\prime}-{ }^{\prime} l a c Z$ expression and modulation by signal. Strains were grown in nutrient yeast broth. $\beta$-Galactosidase activities are mean values of three experiments \pm standard deviation. A, Expression of the $h c n A^{\prime}$ - $^{\prime}$ lacZ fusion carried by pME3219 in CHA0 $\left(\right.$ gac $\left.S^{+}\right)$with

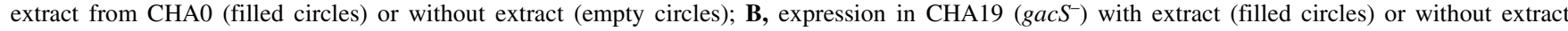
(empty circles); C, expression in CHA19.6 (gacS( $\Delta 128)$ ) with extract (filled circles) or without extract (empty circles).

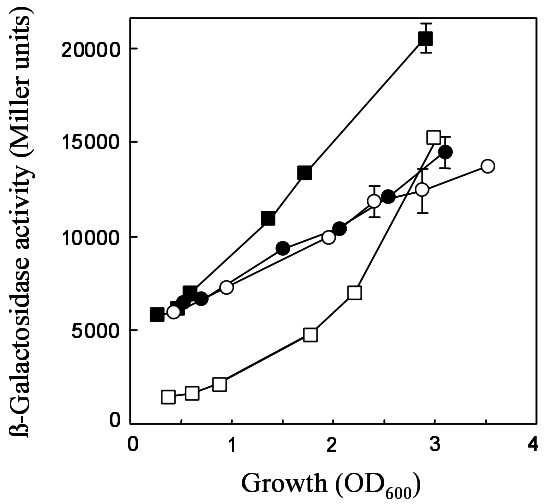

Fig. 3. The $5^{\prime}$ leader region of the $h c n A$ gene is required for responsiveness to signal. $\beta$-Galactosidase activities were determined in triplicate in strain CHA0 carrying pME6531 (ptac-hcnA'-'lacZ) or pME3856 (ptac-lacZ). Both reporter strains were grown in nutrient yeast broth with $1 \mathrm{mM}$ isopropyl- $\beta$-D-thiogalactoside. Empty squares, pME6531 without extract; filled squares, pME6531 with extract; empty circles, pME3856 without extract; filled circles, pME3856 with extract.

peared to be essentially unaffected in the response to signal and in the expression of the reporter gene (Fig. 2C). In this $\operatorname{gac} S(\Delta 128)$ mutant, 128 out of 135 amino acid residues located in the periplasmic loop of the GacS protein are missing (Fig. 1 ), suggesting that this $\mathrm{GacS}$ domain is not essential for signal transduction. As noted before (Heeb et al. 2002), growth rates of $P$. fluorescens strains were similar with or without added extract and only a slight growth lag was observed for the reporter cells in media containing added extract (data not shown).

Several controls were performed. i) A single-copy, chromosomal $h c n A^{\prime}-'$ lacZ reporter fusion in a wild-type background (CHA207) showed the same two- to threefold stimulation of expression by added signal (discussed below) as did the $h c n A^{\prime}$ 'lacZ plasmid pME3219 (Fig. 2A), which has approximately six copies (Heeb et al. 2000), indicating that the copy number of the reporter construct is not a critical parameter. ii) A gacA mutation in the $h c n A^{\prime}$ - $^{\prime}$ lacZ reporter strain CHA89.207 also abolished the response to the signal entirely (data not shown) and the expression of $h c n A^{\prime}$-' $^{\prime} l a c Z$ was very low, as noted before (Blumer et al. 1999). iii) Addition of signal to strain CHA0 carrying the GacS/GacA-controlled phlA'-'lacZ reporter pME6259, which monitors the expression of 2,4-diacetylphloroglucinol biosynthetic genes (Schnider-Keel et al. 2000), also caused a two- to threefold stimulation of phlA expression (data not shown), iv) Activation of target gene expression by the GacS/GacA regulatory system occurs at a posttranscriptional level (Blumer et al. 1999); therefore, we also tested an hcnA'-'lacZ translational fusion construct (pME6531) in which the native $h c n$ promoter had been replaced by the tac promoter (ptac). As expected, expression was markedly induced by added signal in strain CHA0 (Fig. 3), confirming that the native hcn promoter is not required for signal transduction. By contrast, the expression of a construct lacking the $5^{\prime}$ hcnA leader region (i.e., ptac-lacZ [pME3856]) was insensitive to the addition of signal (Fig. 3), in agreement with the previous finding that the repressive RsmA complex acts near the hcnA ribosome binding site (Blumer et al. 1999). Collectively, these results support the model shown in Figure 1 and they establish that an extracellular signal produced by strain $\mathrm{CHA} 0$ can act only when both GacS and GacA are functional.

\section{Construction of a signal-independent gacS mutant.}

To evaluate the importance of the GacS linker region located between the second transmembrane domain and the transmitter domain (Fig. 1), we deleted a segment of 79 amino acids, which contains two putative amphipathic helices (Williams and Stewart 1999). Three new amino acid residues (EAF) were inserted in this process (Fig. 4A). The resulting $\operatorname{gac} S(\Delta 76)$ allele also was placed as a single copy in the CHA0 chromosome previously deleted for gacS. In the resulting strain CHA207.8

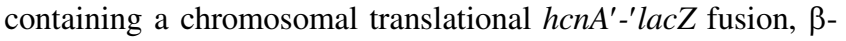
galactosidase expression was insensitive to the addition of signal and enhanced four- to fivefold at low cell densities (i.e., 

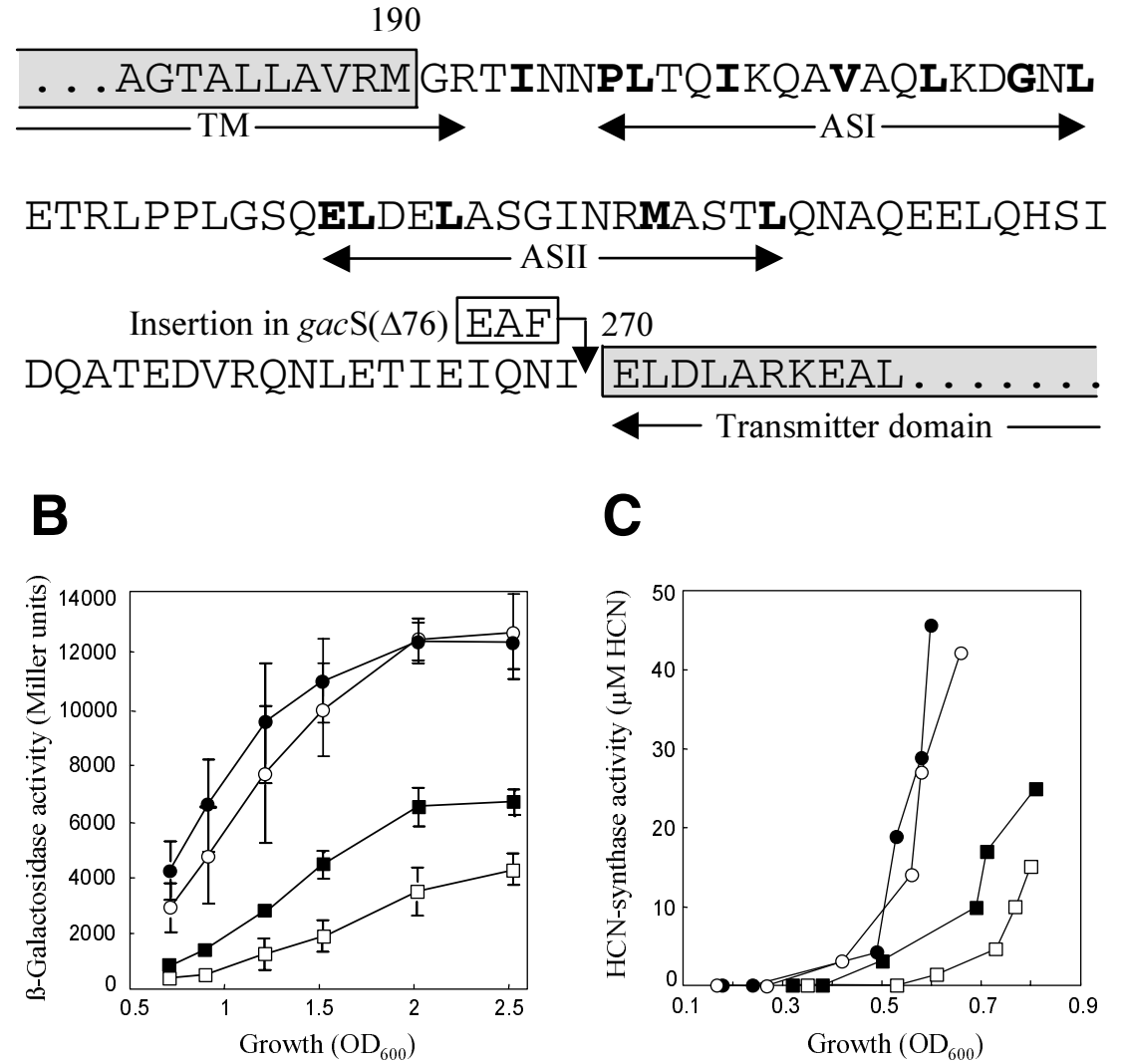

Fig. 4. Deletion of the GacS linker domain and effect of the gacS( $\Delta 76)$ mutation on the expression of the hcn biosynthetic genes. A, Amino acid sequence of the linker region, with two postulated amphipathic helices (ASI, ASII) (Williams and Stewart 1999). TM, transmembrane segment; bold face, conserved residues in sensor kinases (Williams and Stewart 1999). The $\Delta 76$ deletion removes the 79 amino acid residues from Gly191 to Ile 269 of the linker region

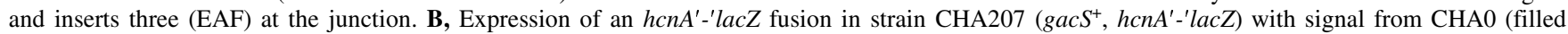
squares) or without signal (empty squares) and in strain CHA207.8 (gacS( $\mathrm{C} 76)$, hcnA'-'lacZ) with signal (filled circles) or without signal (empty circles). C, Hydrogen cyanide (HCN) production by strain $\mathrm{CHA} 0$ with signal (filled squares) or without signal (empty squares) or by strain $\mathrm{CHA} 19.8($ gacS( $\Delta 76)$ ) with signal (filled circles) or without signal (empty circles) growing in glycine minimal medium. Experiments were done three times. Mean values are given in B; C shows a typical experiment. HCN was quantified as previously described (Laville et al. 1998).

below optical density at $\left.600 \mathrm{~nm}\left[\mathrm{OD}_{600}\right]=1.5\right)$, compared with $\beta$-galactosidase expression in the parental $\mathrm{gacS}^{+}$reporter strain CHA207 (Fig. 4B). Thus, the gacS( $\Delta 76)$ mutation locks the system in the "on" position. This was confirmed by following the production of the secondary metabolite HCN itself. In standard nutrient yeast broth (NYB), the production of $\mathrm{HCN}$ is low; therefore, the experiment was performed in a synthetic medium optimized for HCN formation (Castric 1975). Note that, in this medium, growth stops at $\mathrm{OD}_{600} \approx 1.0$. In the gacS $^{+}$ strain $\mathrm{CHA} 0, \mathrm{HCN}$ was synthesized above $\mathrm{OD}_{600}=0.7$. Addition of signal enhanced and advanced $\mathrm{HCN}$ production (Fig. 4C). In the $\operatorname{gac} S(\Delta 76)$ strain CHA19.8, HCN synthesis started early at $\mathrm{OD}_{600}=0.4$ and was not further stimulated by signal (Fig. 4C). Thus, in the gacS( $\Delta 76)$ mutant strain, the need for an activating signal was by-passed.

To show that the effects of signal and the $\operatorname{gac} S(\Delta 76)$ mutation were not restricted to $\mathrm{HCN}$ production, we also examined the expression of aprA encoding the major extracellular protease of strain CHA0. Indeed, the expression of a translational aprA''lacZ fusion in the $\operatorname{gacS}(\Delta 76)$ mutant $\mathrm{CHA} 806.8$ was signal independent, and $\beta$-galactosidase activities were higher than in the wild-type background (CHA805) at low cell densities (Fig. 5). Enhanced and advanced expression in the $\operatorname{gac} S(\Delta 76)$ background

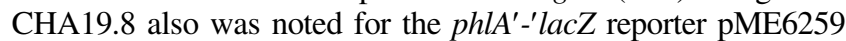
(Fig. 6A). In the mutant CHA19.8 grown in glycerol-casamino acids medium (GCM), the metabolite 2,4-diacetylphloroglucinol was overproduced strongly at low cell densities and also was ele- vated significantly at high cell densities (Fig. 6B). Thus, it is likely that the $\operatorname{gacS}(\Delta 76)$ mutation globally affects $\mathrm{GacS} / \mathrm{GacA}$ dependent expression of exoproduct genes. We noted in these experiments that the growth kinetics of the $\operatorname{gac} S(\Delta 76)$ mutants were similar to those of the gacS $^{+}$wild type, except that the mutants had an extended lag phase when stationary phase cells were inoculated into fresh medium.

\section{Protection of tomato from crown and root rot caused by $\boldsymbol{F}$. oxysporum f. sp. radicis-lycopersici.}

The $\operatorname{gac} S(\Delta 76)$ strain CHA19.8 starts expressing biocontrol traits at lower cell densities than does the wild-type CHA0; therefore, we wondered whether the mutant would have altered, possibly improved biocontrol properties. In a soil-less rockwool system, strain CHA0 protected tomato partially from crown and root rot caused by $F$. oxysporum f. sp. radicislycopersici, as was evident from a significantly lower disease index compared with a control without biocontrol bacteria added (Table 1). The gacS null mutant CHA19 did not afford any protection, and, surprisingly, the $\operatorname{gac} S(\Delta 76)$ mutant CHA19.8 also was unable to protect tomato plants from disease (Table 1). Thus, at least in this gnotobiotic plant-pathogen system, there was no advantage in using signal-independent biocontrol bacteria. Importantly, as observed in other interactions between dicotyledonous plants, root pathogens, and fluorescent pseudomonads, the $\mathrm{GacS} / \mathrm{GacA}$ function clearly was required for biocontrol. 


\section{DISCUSSION}

From a sequence comparison of approximately $20 \mathrm{gacS}$ genes from various pathogenic or beneficial gram-negative bacteria, several features of the GacS sensor kinase have been deduced (Heeb and Haas 2001). In the present study, we have investigated experimentally some of these traits in $P$. fluorescens CHA0, using mutational analysis. First, the three highly conserved amino acid residues and predicted phosphoacceptor sites located in the primary transmitter, the primary receiver, and the carboxy-terminal Hpt domains (Fig. 1) were all found to be essential for $\mathrm{GacS}$ function, as predicted for tripartite sensor kinases (Perraud et al. 1999). Second, the periplasmic domain comprising approximately 135 amino acid residues turned out to be nonessential for GacS activity and for activation of the GacS/GacA pathway by the extracellular signal. This finding is supported by the observation that the periplasmic domain is poorly conserved in GacS from various microorganisms (Heeb and Haas 2001). Third, the GacS linker domain, which contains two relatively well-conserved amphipathic sequences (Heeb and Haas 2001; Williams and Stewart 1999), proved to have an important regulatory function as indicated by the $\operatorname{gac} S(\Delta 76)$ mutation, which locked the GacS protein in an active state, irrespective of the presence of the signal. Similarly, mutations affecting the linker domain of the VirA sensor kinase of Agrobacterium tumefaciens have revealed that

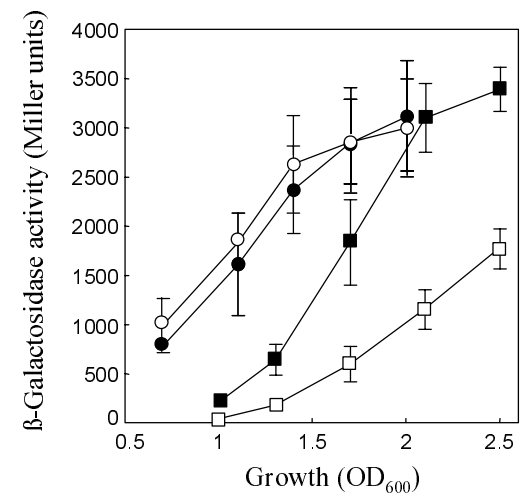

Fig. 5. Elevated, signal-independent expression of an aprA'-'lacZ fusion in a $\operatorname{gac} S(\Delta 76)$ mutant. Expression of an $a p r A^{\prime}-{ }^{\prime} l a c Z$ fusion in strain CHA805 ( gac $^{+}$, aprA $^{\prime}$-'lacZ) growing in nutrient yeast broth with signal (filled squares) or without signal (empty squares) and in strain CHA806.8 ( $\operatorname{gacS}(\Delta 76)$, aprA'-'lacZ) with signal (filled circles) or without signal (empty circles). Measurements were carried out in triplicate. this domain is required for sensing phenolic compounds and low pH (Heath et al. 1995; Toyoda-Yamamoto et al. 2000).

At this stage and in the absence of structural information on the inducing signal of $P$. fluorescens $\mathrm{CHA} 0$, two interpretations of the $\operatorname{gac} S(\Delta 76)$ phenotype can be proposed. The signal might directly interact with GacS and induce a conformational change of the cytoplasmic C-terminal part, thereby favoring autophosphorylation. In this activated state, the amphipathic helices ASI and ASII of the linker domain are proposed to interact (Heeb and Haas, 2001). It is possible that, due to the absence of ASI and ASII in GacS $\Delta 76$, the protein can no longer undergo this conformational switch and has adopted a structure which constantly favors autophosphorylation. Alternatively, the signal might activate some downstream element in the GacS/GacA pathway and deletion of the GacS linker domain might constitutively activate GacS, such that the signal would no longer be able to further stimulate target gene expression. It should be pointed out here that the model shown in Figure 1 is still incomplete. For instance, RsmA is only one of several repressive elements in the $\mathrm{GacS} / \mathrm{GacA}$ system, in that inactivation of $r \operatorname{sm} A$ suppresses a gacS defect only partially (Blumer et al. 1999; Haas et al. 2002). Small regulatory RNAs in addition to RsmZ also may exist in this regulatory network. In principle, any of these components could interact with the activating signal.

In some Pseudomonas strains, the GacS/GacA system has a positive effect on the synthesis of AHL signal molecules (Chancey et al. 1999; Kinscherf and Willis 1999; Reimmann et al. 1997). For instance, in Pseudomonas aeruginosa PAO, GacA-dependent regulation of $\mathrm{HCN}$ formation involves $\mathrm{N}$-(3oxo-dodecanoyl)-homoserine lactone and $\mathrm{N}$-butanoyl-homoserine lactone as signals (Pessi and Haas 2000; Whiteley et al. 1999 ) and in $P$. aureofaciens 30-84, $N$-hexanoyl-homoserine lactone participates in GacA-regulated formation of phenazine compounds (Chancey et al. 1999). However, it has been noted that GacA control of target gene expression in these Pseudomonas strains also can occur in the absence of AHL synthesis (Chancey et al. 1999; Kinscherf and Willis 1999; Pessi and Haas 2001). In P. fluorescens CHA0, no evidence for the production of AHL-type signals has been found (Heeb et al. 2002). This suggests that, in the GacS/GacA pathway, the AHL signals can have a subordinate or lateral role.

In biocontrol of root diseases, one of the most important parameters is the level of root colonization by the biocontrol agent (Paulitz 2000). The production of plant-beneficial secondary metabolites by $P$. fluorescens in vitro requires relatively high cell densities: for efficient expression of the hcn and phl

Table 1. Deletion in the linker domain of GacS in Pseudomonas fluorescens CHA0: Effect on the protection of tomato against root and crown rot caused by F. oxysporum f. sp. radicis-lycopersici ${ }^{\mathrm{V}}$

\begin{tabular}{|c|c|c|c|c|}
\hline \multicolumn{2}{|c|}{ Microorganisms added ${ }^{w}$} & \multirow[b]{2}{*}{ Disease index ${ }^{x}$} & \multirow[b]{2}{*}{ Shoot weight $(g)^{y}$} & \multirow[b]{2}{*}{ Colonization $\left(\log _{10} \mathrm{CFU} / \mathrm{g} \text { of root }\right)^{2}$} \\
\hline P. fluorescens & F. oxysporum f. sp. radicis-lycopersici & & & \\
\hline None & - & $0 \mathrm{c}$ & $0.47 \mathrm{~b}$ & $0 \mathrm{c}$ \\
\hline CHA0 (wild type) & - & $0 \mathrm{c}$ & $0.48 \mathrm{~b}$ & $7.3 \mathrm{~b}$ \\
\hline CHA19 $(\triangle g a c S)$ & - & $0 \mathrm{c}$ & $0.57 \mathrm{a}$ & $7.4 \mathrm{~b}$ \\
\hline CHA19.8 $(\operatorname{gacS}(\Delta 76))$ & - & $0 \mathrm{c}$ & $0.52 \mathrm{ab}$ & $7.5 \mathrm{~b}$ \\
\hline None & + & $2.6 \mathrm{a}$ & $0.28 \mathrm{~d}$ & $0 \mathrm{c}$ \\
\hline CHA0 & + & $1.3 \mathrm{~b}$ & $0.39 \mathrm{c}$ & $8.1 \mathrm{a}$ \\
\hline CHA19 & + & $2.4 \mathrm{a}$ & $0.40 \mathrm{c}$ & $7.8 \mathrm{ab}$ \\
\hline CHA19.8 & + & $2.3 \mathrm{a}$ & $0.36 \mathrm{c}$ & $7.2 \mathrm{~b}$ \\
\hline
\end{tabular}

${ }^{\mathrm{v}}$ Means within the same column followed by the same letter do not differ significantly at $P=0.05$, according to Student's $t$ test. Data represent three individual repetitions of the same experimental setup. Treatments consisted of 12 plants and were replicated three times in each experiment.

${ }^{\mathrm{w}}$ P. fluorescens strains and $F$. oxysporum f. sp. radicis-lycopersici were added at $10^{8} \mathrm{CFU}$ and $10^{6}$ conidia per seedling, respectively. Plants were grown in a soil-less rockwool system for 14 days.

${ }^{\mathrm{x}}$ Disease severity was scored on a scale of 0 to 4 in which $0=$ symptomless and $4=$ dead or nearly so.

y Shoot fresh weight.

${ }^{\mathrm{z}}$ Root colonization by $P$. fluorescens. 
genes in liquid cultures $\geq 10^{9} \mathrm{CFU} / \mathrm{ml}$ are needed, considering that $\mathrm{OD}_{600}=1$ corresponds to approximately $10^{9} \mathrm{CFU} / \mathrm{ml}$ (Figs. 4B and 6). Although these cell densities in liquid media cannot be directly correlated with bacterial densities on roots (expressed as CFU per gram of root), it is well established that biocontrol effects are observed above threshold levels of typically $>10^{5}$ to $10^{7} \mathrm{CFU} / \mathrm{g}$ (Bull et al. 1991; Paulitz 2000; Raaijmakers et al. 1995). For these reasons, we were interested to test the biocontrol efficacy of the $\operatorname{gac} S(\Delta 76)$ strain CHA19.8, which shows an approximately 10-fold increased expression of the $h c n$ and $p h l$ genes at $\mathrm{OD}_{600} \leq 1.0$, compared with the wild type (Figs. 4B and 6). However, in the soil-less plant-pathogen system used (Table 1 ), the gacS( $\Delta 76)$ mutant's biocontrol ability was largely abolished compared with that of the wild type. As shown in Figure 6B, 2,4-diacetylphloroglucinol was produced constitutively by the $\operatorname{gac} S(\Delta 76)$ mutant and accumulated to high levels, compared with the wild-type CHA0. F. oxysporum f. sp. radicis-lycopersici is highly sensitive to this antibiotic in vitro (Duffy and Défago 1997; Keel et al. 1992; Maurhofer et al. 1995) and, therefore, loss of biocontrol activity in strain CHA19.8 may seem surprising. In the presence of $F$. oxysporum f. sp. radicis-lycopersici, strain CHA19.8 gave significantly lower root colonization than did the wild type (Table 1). However, colonization by strain CHA19.8 still exceeded $10^{7} \mathrm{CFU} / \mathrm{g}$ of root and, therefore, should be above the typical threshold level. Moreover, the complemented gacS mutant CHA19.1, which was used as a control in the same experiment, gave wild-type protection at a root colonization of $10^{7} \mathrm{CFU} / \mathrm{g}$ of root (data not shown). Therefore, we assume that reduced root colonization was not the major reason for the failure of CHA19.8 to suppress disease. Overproduction of 2,4-diacetylphloroglucinol by this strain might be toxic to the host plant in the presence of $F$. oxysporum f. sp. radicis-lycopersici, such that toxicity might cancel a positive biocontrol effect. It has been shown previously that tomato is, indeed, sensitive to low concentrations of 2,4diacetylphloroglucinol, ranging from 3 to $50 \mu \mathrm{M}$ (Keel et al. 1992; Maurhofer et al. 1995). There are other examples of antibiotic overproduction by biocontrol strains that have not resulted in improved biocontrol. For instance, overproduction of 2,4-diacetylphloroglucinol and pyoluteorin by strain $\mathrm{CHA} 0$ containing additional copies of the housekeeping sigma factor rpoD has provided improved biocontrol of Pythium ultimum on cucumber (Schnider et al. 1995), but this overproducing strain has been less efficient than the wild type in suppressing disease in other plant-pathogen systems, such as Pythium ultimumcress, Pythium ultimum-sweet corn, and Gaeumannomyces graminis-wheat (Maurhofer et al. 1992, 1995). In vitro, strain
CHA19.8 showed a longer lag phase, compared with the wildtype CHA0. Whether this situation also applies to the biocontrol assay is not certain, because only one point in time (at 14 days) was measured. However, a kinetic analysis of antibiotic production and of $F$. oxysporum $\mathrm{f}$. sp. radicis-lycopersici proliferation in the rhizosphere would have been warranted if the signal-independent derivative had given superior biocontrol effects.

Care was taken to study the effects of $g a c S$ mutations at the single-copy level. To achieve this objective, we used an improved mini-Tn7 delivery system described in Figure 7, which allows the transpositional insertion of modified mini- $\mathrm{Tn} 7 \mathrm{con}$ structs into the unique $\mathrm{Tn} 7$ attachment site in the chromosome of many gram-negative bacteria (Bao et al. 1991; Højberg et al. 1999; Koch et al. 2001). These singly-copy delivery vectors also are proving to be useful in $P$. aeruginosa (unpublished data).

\section{MATERIALS AND METHODS}

Bacterial strains, plasmids, and growth conditions.

P. fluorescens strains and plasmids used are listed in Table 2. Strains were routinely grown in NYB or on nutrient agar (Stanisich and Holloway 1972) at $30^{\circ} \mathrm{C}$ (P. fluorescens) or $37^{\circ} \mathrm{C}$ (E. coli). Strain CHA0 was cultivated in GCM containing $100 \mu \mathrm{M} \mathrm{FeCl}{ }_{3} 6 \mathrm{H}_{2} \mathrm{O}$ and $100 \mu \mathrm{M} \mathrm{ZnCl}_{2}$ (Schnider-Keel et al. 2000) for signal extraction, in glycine minimal medium (Castric 1975) for HCN determinations, or in Ornston Stanier (OS) minimal medium with glucose (Schnider-Keel et al. 2000) for phlA expression experiments. Antibiotic concentrations have been detailed before (Blumer et al. 1999; Heeb et al. 2002; Schnider-Keel et al. 2000).

\section{DNA manipulation and plasmid constructions.}

Standard methods were used for the preparation of chromosomal and plasmid DNA, electroporation and transformation, Southern blotting, and cloning procedures (Farinha and Kropinski 1990; Sambrook et al. 1989; Schnider et al. 1995). The lacI ${ }^{Q}$-ptac segment of pJF118EH, bordered by NruI and $K p n I$ sites, was used to create pME6531, a $l a c I^{Q}$ derivative of pME6530. Plasmid pME3856 (lacI ${ }^{Q}$ ptac-lacZ) was constructed from the $l a c I^{Q}$-ptac segment of pJF118EH, the lacZ gene with its own RBS of pME3535, and vector pME6010. Construction of the mini-Tn7 carrier plasmids pME3280a and pME3280b was done in several steps. Polymerase chain reaction (PCR) amplification using the primers $\mathrm{Gm} 1{ }^{\prime} 5^{\prime}-$ GACGCACACCGTGGAAA-3') and Gm2 (5'-GCGGCGTTGTGACAATTT- $3^{\prime}$ ) and the Gm-resistant plasmid pML8 as
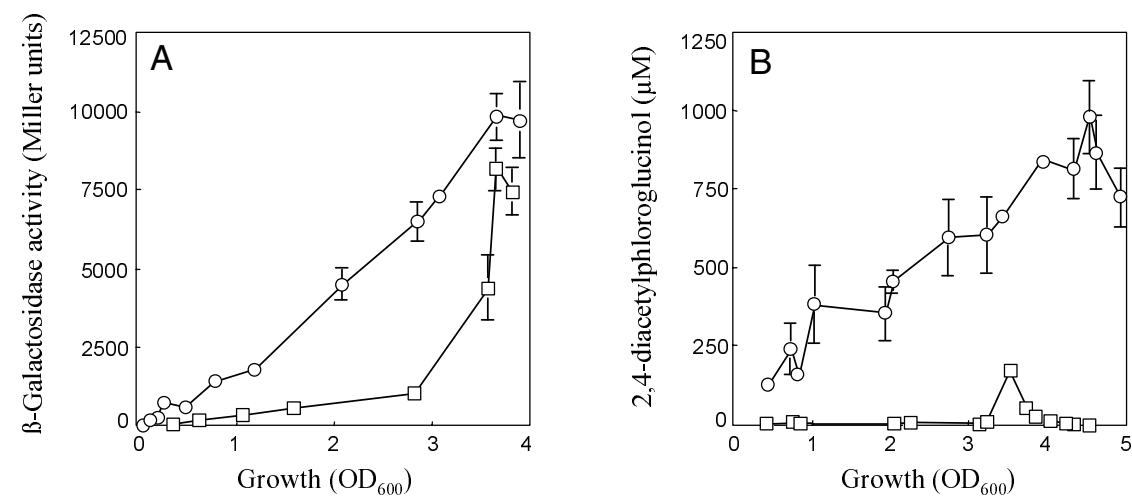

Fig. 6. Effect of the $\operatorname{gac} S(\Delta 76)$ mutation on the expression of the $p h l$ biosynthetic genes. A, Expression of the phlA'-'lacZ construct pME6259 was tested in strain CHA0 (empty squares) and in the mutant CHA19.8 (empty circles) growing in Ornston Stanier minimal medium with glucose; B, 2,4diacetylphloroglucinol production by strain CHA0 (empty squares) or by strain CHA19.8 (empty circles) grown in glycerol-casamino acids medium. Measurements were carried out in triplicate. 
a template produced a $0.85-\mathrm{kb}$ fragment which was treated with T4 DNA polymerase and cloned into the HincII site of pBluescript. The Gm resistance cassette then was excised with $K p n I$ and $S a c I$ and used to replace the SalI fragment of pUX-BF5 carrying the kanamycin resistance gene. The ends were made compatible with T4 DNA polymerase. The Gm resistance pUX-BF5 variant was linearized with HindIII, treated with T4 DNA polymerase, and cleaved with SpeI to give a fragment $(\mathrm{X})$ of $5.9 \mathrm{~kb}$. A second fragment of $0.35 \mathrm{~kb}$ (Y), which carries a translation stop signal (Ter; Fig. 7A) was obtained from $\mathrm{pHP} 45 \Omega \mathrm{Sm} / \mathrm{Sp}$ by cleavage with $S p h \mathrm{I}$ and HindIII; the SphI end was made flush with T4 DNA polymerase. Ligation of fragments $\mathrm{X}$ and $\mathrm{Y}$ to the left half of the pUK21 polylinker (SpeI-StuI-XhoI-SphI-NcoI-KpnISmaI-EcoRI-HindIII) generated pME3280a, whereas ligation to the right half (HindIII-PstI-MluI-BamHI-SpeI) gave pME3280b (Fig. 7A).

The gacS gene of strain CHA0 was isolated from a partial genomic library (pBluescript KS containing BamHI fragments of 5 to $9 \mathrm{~kb}$ from strain CHA0) in E. coli DH5 $\alpha$. A recombinant plasmid which hybridized with a 6.7-kb KpnI fragment containing gacS (=apdA) from pJEL5680 (Corbell and Loper 1995) carried the gacS gene of strain $\mathrm{CHA} 0$ on an $8.5-\mathrm{kb}$ insert. Nucleotide sequencing (carried out by Microsynth, Balgach, Switzerland) was used to localize gacS to a $4.1-\mathrm{kb}$ BamHI-BsiWI fragment. This fragment (Fig. 7B) was cloned into the vector pME6010, resulting in pME3258, which complemented the gacS mutant CHA510 but not the gacA mutant CHA89. A gacS null mutant (CHA19) was constructed by deleting the entire $g a c S$ gene (on a 3.2-kb EcoRV-BsiWI fragment) and by transferring this mutation to the CHA0 chromo- some using the suicide vector pME3087, as previously described (Laville et al. 1998; Schnider et al. 1995); strain CHA19 was checked by Southern blotting (data not shown).

The $\operatorname{gac} S(\Delta 76)$ allele was constructed by joining a PCRamplified 5' gacS fragment (nucleotides 1 [being the first nucleotide specifying the EcoRV recognition site; Fig. 7B] to 971) to an amplified $3^{\prime}$ gacS fragment (nucleotides 1,205 to 3,225) via an artificial HindIII linker sequence (CAAGCTT), creating in the GacS polypeptide a deletion of 79 amino acid residues between Met-190 and Glu-270, fused with a GluAla-Phe linker (Figs. 1 and $4 \mathrm{~A}$ ). The resulting $\operatorname{gac} S(\Delta 76)$ allele containing its own promoter was checked by sequencing and inserted into the suicide cloning vector pME3280a (Fig. 7A), which delivers the mini-Tn7 with passenger DNA into the unique $\mathrm{Tn} 7$ attachment site of the $P$. fluorescens chromosome in the presence of the Tn7 transposition helper pUX-BF13 (Bao et al. 1991; Højberg et al. 1999; Koch et al. 2001). Thus, strains CHA19.8 [ $\Delta$ gacS/gacS( 476$)$ in att $\operatorname{Tn} 7]$, CHA207.8 [hcnA' -'lacZ gacS::Tn5/gacS( 476$)$ in att Tn7], and CHA806.8 [aprA'-'lacZ $\Delta$ gacS/gacS $(\Delta 76)$ in $\operatorname{att} \mathrm{Tn} 7]$ were obtained and checked by Southern blotting (data not shown).

For the construction of $\operatorname{gacS}(\Delta 128)$, the $5^{\prime}$ region of $\mathrm{gacS}$ (nucleotides 1 [being the first nucleotide specifying the EcoRV recognition site; Fig. 7B] to 505) was PCR-amplified from an EcoRV-BsiWI gacS subclone using a vector primer and primer LoSph (5'-AGAGCTGCATGCAGGTGAAGT$3^{\prime}$ ), which, due to a single base change (written in bold face) introduces an artificial SphI site (underlined) and changes the 32nd codon from Trp to Cys. The PCR fragment was fused at its $S p h \mathrm{I}$ site to a $S p h \mathrm{I}-B s i \mathrm{WI}$ fragment encompassing the 3' region of gacS (nucleotides 883 to 3,225). This created a
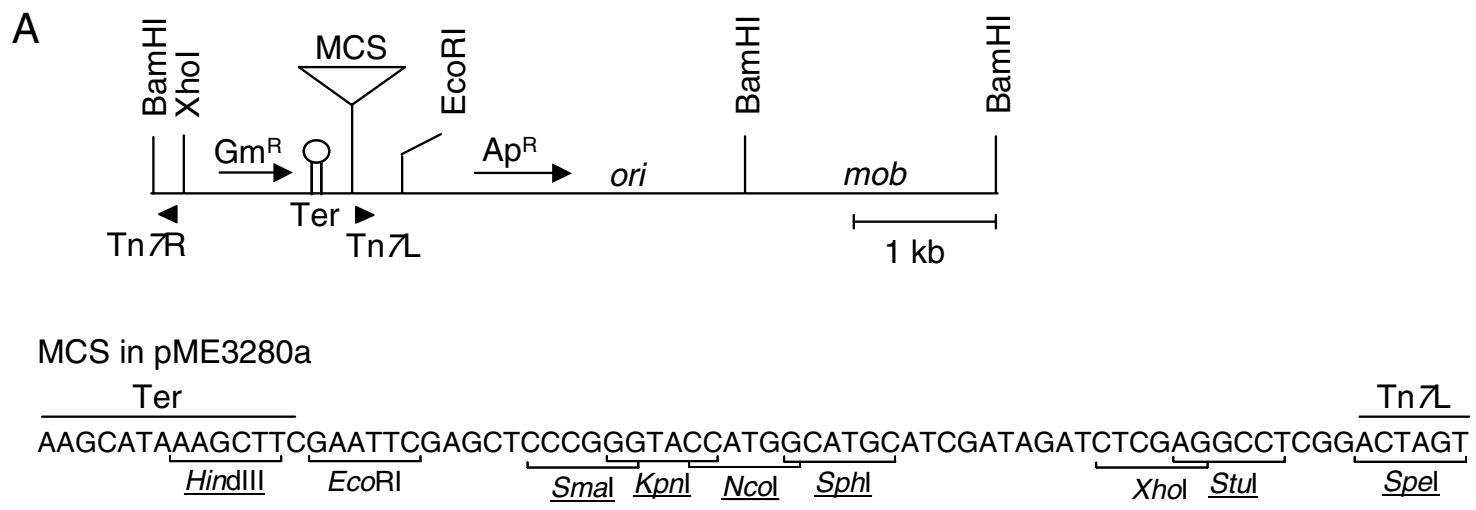

MCS in pME3280b

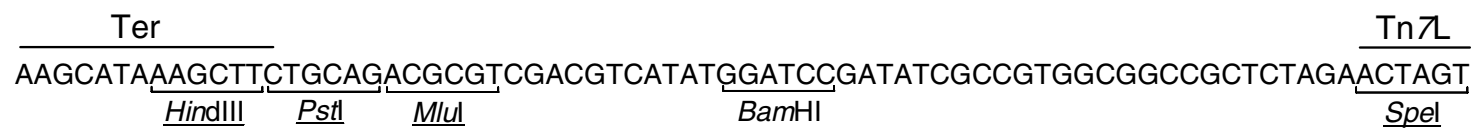

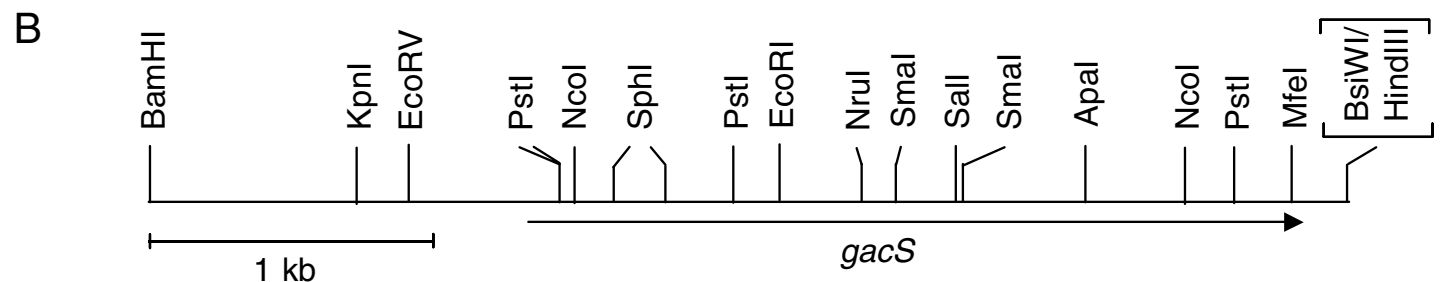

Fig. 7. Mini-Tn7 delivery vectors and gacS of $P$. fluorescens. A, The Gm-resistant mini-Tn7 vectors were derived from pUX-BF5 as described in Materials and Methods. MCS, multiple cloning site; Ter, transcription terminator; Tn7L, Tn7R, left and right borders, respectively, of Tn7. Unique restriction sites are underlined. B, Restriction map of the gacS region of Pseudomonas fluorescens CHA0, cloned in the pME6010-derivative pME3558. 
384-bp deletion in $g a c S$, removing the first 128 codons specifying the periplasmic loop. Thus, in the $\operatorname{GacS}(\Delta 128)$ polypeptide, 128 amino acids located between Met-33 and Leu162 (Fig. 1) were deleted. The gacS $(\Delta 128)$ mutant allele with its promoter was inserted into mini-Tn7 of pME3280a, as above, and transposed into the chromosome of CHA19 $(\Delta g a c S)$, resulting in strain CHA19.6 $[\Delta \operatorname{gacS} / \operatorname{gac} S(\Delta 128)$ in att $\operatorname{Tn} 7]$.

To generate the H294R mutation in GacS, a 1.9-kb EcoRVSalI fragment carrying the $5^{\prime}$ part of gacS was cloned into pBluescript KS and subjected to site-directed mutagenesis using the Chameleon double-stranded site-directed mutagenesis kit and the mismatch repair-defective $E$. coli strain XL-mutS (Stratagene Inc., La Jolla, CA, U.S.A.) (Deng and Nickoloff, 1992). The selection primer Sel (5'GTGGCGGCCGCTCGCAAACTAGTGGATC- $3^{\prime}$ ) and the mutagenic primer MutHis294 (5'-CCTGGCCAACATGTCTCGAGAAATCCGTACACC-3') were used; nucleotides differing from the parental DNA are shown in bold face. Thus, the $g a c S$ wild-type sequence 5'-AGCCATGAA-3' (Ser His Glu) was changed to 5'-TCTCGAGAA-3' (Ser Arg Glu) containing an XhoI site (underlined) for screening. For the introduction of the $\mathrm{D} 717 \mathrm{~N}$ and H863R mutations, a $0.9-\mathrm{kb}$ ApaI-BsiWI fragment carrying the $3^{\prime}$ part of the gacS was inserted into pBluescript and subjected to mutagenesis, using the selection primer Sel and the mutagenic primers
MutAsp717 (5'-GACCTGGTAATGATGAACGTTCAGATGCCCGGC-3') and MutHis863 (5'-GATCGAACGGGTCCGTCGACTGCACGGTGCCACC-3'), respectively; nucleotides differing from parental DNA are indicated in bold face. Thus, the gacS wild-type sequences 5'-ATGGACGTG-3' (Met Asp Val) and 5'-GTCCACCGCCTG-3' (Val His Arg Leu) were changed to 5'-ATG and 5'-GTCCGTCGACTG-3' (Val Arg Arg Leu), respectively. New restriction sites (underlined) for AclI and SalI, respectively, were created for screening. Each of the three mutations generated was verified by sequencing, integrated into the entire gacS gene (carried by the 3.2-kb EcoRV$B s i$ WI fragment), and moved to the chromosome of strain CHA19, using mini-Tn7 transposition as above. In this way, strains CHA19.3 (gacS H294R), CHA19.4 (gacS D717N), and CHA19.5 (gacS H863R) were obtained. As a control, the unmutated $g a c S$ gene also was introduced into the $a t t \mathrm{Tn} 7$ site of strain CHA19, resulting in strain CHA19.1 ( gac $\left.^{+}\right)$. This strain was phenotypically indistinguishable from the wildtype CHA0. All constructs were checked by Southern blotting.

Extraction of signal from cell-free culture supernatants and biological assays for the presence of signal.

Strain CHA0 was grown in $500 \mathrm{ml}$ of GCM in a 2-liter Erlenmeyer flask for $24 \mathrm{~h}$, with shaking, to an $\mathrm{OD}_{600}$ of 2.0 to 2.5. After cell removal by centrifugation, the supernatant

Table 2. Bacterial strains and plasmids

\begin{tabular}{|c|c|c|}
\hline Strain or plasmid & Relevant characteristics ${ }^{\mathrm{z}}$ & Source \\
\hline \multicolumn{3}{|l|}{ Strains } \\
\hline \multicolumn{3}{|l|}{ Escherichia coli } \\
\hline DH5 $\alpha$ & recA1 endA1 hsdR17 deoR thi-1 supE44 gyrA96 relA1 $\Delta($ lacZYA-argF) U169 (\$80dlacZAM15) & Sambrook et al. 1989 \\
\hline \multirow[t]{2}{*}{ XL-mutS } & $\Delta(m c r A) 183 \triangle(m c r C B$ hsdSMR mrr $) 173$ endA1 supE44 thi-1 gyrA96 relA1 lac mutS::Tn10 $\left(\mathrm{Tc}^{\mathrm{r}}\right)$ & \\
\hline & F'proAB lacl ${ }^{Q} \mathrm{Z} \Delta \mathrm{M} 15 \mathrm{Tn} 5 ; \mathrm{Km}^{\mathrm{r}}$ & Stratagene \\
\hline \multicolumn{3}{|c|}{ Pseudomonas fluorescens } \\
\hline CHA0 & Wild type & Voisard et al. 1994 \\
\hline CHA19 & $\triangle g a c S$ & This study \\
\hline CHA19.1 & $\Delta g a c S / m i n i-T n 7 \mathrm{Gm}^{\mathrm{r}} \mathrm{gacS}^{+}$ & This study \\
\hline CHA19.3 & $\Delta \operatorname{gacS} / \mathrm{mini}-\mathrm{Tn} 7 \mathrm{Gm}^{\mathrm{r}} \operatorname{gac} \mathrm{g}(\mathrm{H} 294 \mathrm{R})$ & This study \\
\hline CHA19.4 & $\Delta g a c S / m i n i-T n 7 \mathrm{Gm}^{\mathrm{r}} \operatorname{gacS}(\mathrm{D} 717 \mathrm{~N})$ & This study \\
\hline CHA19.5 & $\Delta$ gacS/mini-Tn7 $\mathrm{Gm}^{\mathrm{r}} \operatorname{gac} S(\mathrm{H} 863 \mathrm{R})$ & This study \\
\hline CHA19.6 & $\Delta g a c S / m i n i-T n 7 \mathrm{Gm}^{\mathrm{r}} \operatorname{gac} S(\Delta 128)$; periplasmic loop mutant & This study \\
\hline CHA19.8 & $\Delta g a c S /$ mini-Tn7 $\mathrm{Gm}^{\mathrm{r}} \operatorname{gacS}(\Delta 76) ;$ linker domain mutant & This study \\
\hline CHA89 & $\operatorname{gac} A: \because \mathrm{Km}^{\mathrm{r}}$ & Laville et al. 1992 \\
\hline CHA89.207 & gacA :: $\mathrm{Km}^{\mathrm{r}}$ hcnA'-'lacZ & Blumer et al. 1999 \\
\hline CHA207 & henA'-'lacZ & Blumer et al. 1999 \\
\hline CHA207.8 & gacS::Tn5/mini-Tn7 $\mathrm{Gm}^{\mathrm{r}}$ gacS $(\Delta 76)$ hcnA'-'lacZ & This study \\
\hline CHA510 & gacS::Tn5 & Bull et al. 2001 \\
\hline CHA805 & aprA'-'lacZ & Blumer et al. 1999 \\
\hline CHA806 & $\triangle g a c S$ aprA'-'lacZ & Heeb et al. 2002 \\
\hline CHA806.8 & $\Delta g a c S / m i n i-T n 7 \mathrm{Gm}^{\mathrm{r}} \operatorname{gac} S(\Delta 76) a p r A^{\prime}-{ }^{\prime} l a c Z$ & This study \\
\hline \multicolumn{3}{|l|}{ Plasmids } \\
\hline pBLS II KS & Cloning vector, $\mathrm{Ap}^{\mathrm{r}}$ & Stratagene \\
\hline $\mathrm{pHP} 45 \Omega \mathrm{Sm} / \mathrm{Sp}$ & Source of transcription/translation stop cassette; $\mathrm{Ap}^{\mathrm{r}}, \mathrm{Sm}^{\mathrm{r}}, \mathrm{Sp}^{\mathrm{r}}$ & Prentki and Krisch 1984 \\
\hline pJEL5680 & $\operatorname{gacS}^{+}\left(=a p d A^{+}\right), \mathrm{Ap}^{\mathrm{r}}$ & Corbell and Loper 1995 \\
\hline pJF118EH & 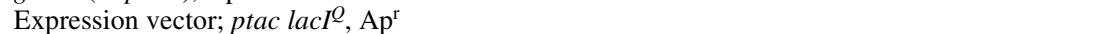 & Fürste et al. 1986 \\
\hline pME3087 & Suicide vector, $\mathrm{MCS}, \mathrm{Tc}^{\mathrm{r}}$ & Voisard et al. 1994 \\
\hline pME3219 & $h c n A^{\prime}-{ }^{\prime} l a c Z, \mathrm{Tc}^{\mathrm{r}}$ & Blumer et al. 1999 \\
\hline pME3258 & $\operatorname{gac}^{+}, \mathrm{Tc}^{\mathrm{r}}, \mathrm{pME} 6010$ derivative & This study (Fig. 7B) \\
\hline pME3280a,b & Chromosomal integration vectors, mini- $\mathrm{Tn} 7 \mathrm{Gm}^{\mathrm{r}}, \mathrm{MCS}$ & This study (Fig. 7A) \\
\hline pME3535 & Transcriptional fusion vector, $\operatorname{lac} Z, \mathrm{MCS}, \mathrm{Ap}^{\mathrm{r}}$ & Højberg et al. 1999 \\
\hline pME3856 & ptac-lacZ lacI ${ }^{Q}, \mathrm{Tc}^{\mathrm{r}}$, pME6010 derivative & This study \\
\hline pME6010 & Cloning vector, $\mathrm{MCS}, \mathrm{Tc}^{\mathrm{r}}$ & Heeb et al. 2000 \\
\hline pME6259 & phlA'-'lacZ, $\mathrm{Tc}^{\mathrm{r}}$ & Schnider-Keel et al. 2000 \\
\hline pME6530 & ptac-hcnA'-'lacZ, $\mathrm{Tc}^{\mathrm{r}}$ & Blumer et al. 1999 \\
\hline pME6531 & ptac-hcnA'-'lacZ, lacI $Q, \mathrm{Tc}^{\mathrm{r}}$ & This study \\
\hline pML8 & Source of $\mathrm{Gm}^{\mathrm{r}}$ cassette, $\mathrm{Ap}^{\mathrm{r}}, \mathrm{Gm}^{\mathrm{r}}$ & Labes et al. 1990 \\
\hline pUK21 & Cloning vector, $\mathrm{MCS}, \mathrm{Km}^{\mathrm{r}}$ & Vieira and Messing 1991 \\
\hline pUX-BF5 & $\operatorname{mini}-\mathrm{Tn} 7 \mathrm{Km}^{\mathrm{r}}, \mathrm{Ap}^{\mathrm{r}}$ & Bao et al. 1991 \\
\hline pUX-BF13 & Helper plasmid encoding $T n 7$ transposition functions, $A p^{r}$ & Bao et al. 1991 \\
\hline
\end{tabular}

\footnotetext{
${ }^{\mathrm{z}} \mathrm{Ap}=$ ampicillin $; \mathrm{Gm}=$ gentamicin $; \mathrm{Km}=$ kanamycin; $\mathrm{Sm}=$ streptomycin; $\mathrm{Sp}=$ spectinomycin; $\mathrm{Tc}=$ tetracycline; and MCS = multiple cloning site.
} 
was processed and extracted with dichloromethane to provide the CHA0 signal, as previously described (Heeb et al. 2002). $P$. fluorescens reporter strains carrying a translational $h c n A^{\prime}$ 'lacZ, aprA'-lacZ, or phlA'-'lacZ fusion either in the chromosome or on a plasmid were grown in 50-ml Erlenmeyer flasks with $20 \mathrm{ml}$ of NYB containing $0.05 \%$ Triton X100 , with shaking $(180 \mathrm{rpm})$. Routinely, an equivalent of 50 $\mathrm{ml}$ of extracted supernatant was dissolved in $200 \mu \mathrm{l}$ of $50 \%$ ( $\mathrm{vol} / \mathrm{vol})$ acetonitrile and added to the medium at the beginning of the experiment. Controls had $200 \mu \mathrm{l}$ of $50 \%$ ( $\mathrm{vol} / \mathrm{vol}$ ) acetonitrile alone. Cultures were inoculated with washed cells $(1: 200)$ to give an initial $\mathrm{OD}_{600}$ of 0.01 and assayed for $\beta$-galactosidase at different times by the Miller method (Sambrook et al. 1989). The amount of signal present in 50 $\mathrm{ml}$ of culture supernatant gave a maximal (saturating) response in the bioassays.

\section{Detection of GacS/GacA-dependent phenotypes.}

$\mathrm{HCN}$, AprA protease, 2,4-diacetylphloroglucinol, and tryptophan side chain oxidase were tested qualitatively as previously described (Laville et al. 1992; Sacherer et al. 1994; Schnider et al. 1995; Voisard et al. 1989). Quantitative HCN and 2,4-diacetylphloroglucinol assays also were performed as described before (Keel et al. 1992; Laville et al. 1998; Schnider-Keel et al. 2000).

\section{Biocontrol assay.}

The ability of $P$. fluorescens $\mathrm{CHA} 0$ and its mutants to protect tomato against Fusarium crown and root rot was studied in a noncirculating hydroponics system. Seeds of tomato (Lycopersicon esculentum cv. Supermarmande) were surfacedisinfested in $1 \%$ sodium hypochlorite for $30 \mathrm{~min}$, rinsed in sterile distilled water, and germinated on $0.85 \%$ water agar at $24^{\circ} \mathrm{C}$ for 3 days. The seedlings were transferred to rockwool cubes (type A0 36/40-6/15; Grodania A/S, Hedehusene, Denmark) placed in individual trays (12 cubes per tray, 1 cube per plant). The cubes were saturated with sterile Knop nutrient solution (Duffy and Défago 1999) throughout the experiment. Two hours after planting, $1 \mathrm{ml}$ of a suspension with $1 \times 10^{6}$ microconidia plus mycelial fragments of $F$. oxysporum f. sp. radicis-lycopersici strain 22 (obtained from C. Alabouvette, INRA, Dijon, France) was added per plant. The inoculum was prepared from a $2 \%$ Difco malt extract culture of the fungus grown with orbital shaking $(120 \mathrm{rpm})$ at $24^{\circ} \mathrm{C}$ for 4 days as detailed elsewhere (Duffy and Défago 1997). One hour later, $1 \mathrm{ml}$ of a suspension of washed bacterial cells $\left(1.5 \times 10^{8} \mathrm{CFU} / \mathrm{ml}\right)$ was added per plant. The trays were placed in a randomized block design in a growth chamber at $80 \%$ relative humidity and $22^{\circ} \mathrm{C}$ with light $(300$ $\mu \mathrm{mol} / \mathrm{sec} / \mathrm{m}^{2}$; ratio of 1.37 of light at $660 \mathrm{~nm}$ to $730 \mathrm{~nm}$ ) for $16 \mathrm{~h}$, followed by an 8 -h dark period at $18^{\circ} \mathrm{C}$. Disease severity was assessed after 14 days, using the following scale: $0=$ plant healthy; $1=$ one or two necrotic lesions on the roots or the crown; 2 = extensive crown necrosis; $3=$ extensive crown and root necrosis, but plant still alive; and $4=$ plant dead or nearly so. Each experiment was repeated three times, with three replicates per treatment in each experiment and with each replicate consisting of 12 plants.

\section{ACKNOWLEDGMENTS}

We thank M. Péchy and G. Défago for communication of unpublished data and for discussion. This work was supported by the Swiss National Science Foundation (project 31-56608.99), the European Union project QLK3-2000-31759 ECO-SAFE, the Swiss Priority Program Biotechnology (projects 5002-045023/1 and 5002-41747), and an OECD fellowship to F. Carruthers.

\section{LITERATURE CITED}

Aarons, S., Abbas, A., Adams, C., Fenton, A., and O'Gara, F. 2000. A regulatory RNA (PrrB RNA) modulates expression of secondary metabolite genes in Pseudomonas fluorescens F113. J. Bacteriol. 182:3913-3919.

Altier, C., Suyemoto, M., Ruiz, A. I., Burnham, K. D., and Maurer, R. 2000. Characterization of two novel regulatory genes affecting Salmonella invasion gene expression. Mol. Microbiol. 35:635-646.

Baker, C. S., Morozov, I., Suzuki, K., Romeo, T., and Babitzke, P. 2002. CsrA regulates glycogen biosynthesis by preventing translation of $g \lg C$ in Escherichia coli. Mol. Microbiol. 44:1599-1610.

Bao, Y., Lies, D. P., Fu, H., and Roberts, G. P. 1991. An improved Tn7 system for the single-copy insertion of cloned genes into chromosomes of Gram-negative bacteria. Gene 109:167-168.

Bleecker, A. B., Esch, J. J., Hall, A. E., Rodriguez, F. I., and Binder, B. M. 1998. The ethylene-receptor family from Arabidopsis: structure and function. Phil. Trans. R. Soc. Lond. B. Biol. Sci. 353:1405-1412.

Bloemberg, G. V., and Lugtenberg, B. J. J. 2001. Molecular basis of plant growth promotion and biocontrol by rhizobacteria. Curr. Opin. Plant Biol. 4:343-350.

Blumer, C., and Haas, D. 2000. Mechanism, regulation and ecological role of bacterial cyanide biosynthesis. Arch. Microbiol. 173:170-177.

Blumer, C., Heeb, S., Pessi, G., and Haas, D. 1999. Global GacA-steered control of cyanide and exoprotease production in Pseudomonas fluorescens involves specific ribosome binding sites. Proc. Natl. Acad. Sci. U.S.A. 96:14073-14078.

Brinkman, F. S. L., Macfarlane, E. L. A., Warrener, P., and Hancock, R. E. W. 2001. Evolutionary relationships among virulence-associated histidine kinases. Infect. Immun. 69:5207-5211.

Bull, C. T., Duffy, B., Voisard, C., Défago, G., Keel, C., and Haas, D. 2001. Characterization of spontaneous gacS and gacA regulatory mutants of Pseudomonas fluorescens biocontrol strain CHA0. Antonie Leeuwenhoek 79:327-336.

Bull, C. T., Weller, D. M., and Thomashow, L. S. 1991. Relationship between root colonization and suppression of Gaeumannomyces graminis var. tritici by Pseudomonas fluorescens strain 2-79. Phytopathology 81:954-959.

Castric, P. A. 1975. Hydrogen cyanide, a secondary metabolite of Pseudomonas aeruginosa. Can. J. Microbiol. 21:613-618.

Chancey, S. T., Wood, D. W., and Pierson, L. S. 1999. Two-component transcriptional regulation of $\mathrm{N}$-acyl-homoserine lactone production in Pseudomonas aureofaciens. Appl. Environ. Microbiol. 65:2294-2299.

Chancey, S. T., Wood, D. W., Pierson, E. A., and Pierson III, L. S. 2002. Survival of GacS/GacA mutants of the biological control bacterium Pseudomonas aureofaciens 30-84 in the wheat rhizosphere. Appl. Environ. Microbiol. 68:3308-3314.

Corbell, N., and Loper, J. E. 1995. A global regulator of secondary metabolite production in Pseudomonas fluorescens Pf-5. J. Bacteriol. 177:6230-6236.

Cui, Y., Chatterjee, A., and Chatterjee, A. K. 2001. Effects of the twocomponent system comprising GacA and GacS of Erwinia carotovora subsp. carotovora on the production of global regulatory rsmB RNA,

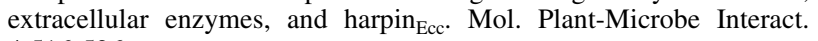
4:516-526.

Deng, W. P., and Nickoloff, J. A. 1992. Site-directed mutagenesis of virtually any plasmid by eliminating a unique site. Anal. Biochem. 200:81-88.

Duffy, B., and Défago, G. 1997. Zinc improves biocontrol of Fusarium crown and root rot of tomato by Pseudomonas fluorescens and represses the production of pathogen metabolites inhibitory to bacterial antibiotic biosynthesis. Phytopathology 87:1250-1257.

Duffy, B. K., and Défago, G. 1999. Macro- and microelement fertilizers influence the severity of Fusarium crown and root rot of tomato in a soilless production system. HortScience 34:287-291.

Farinha, M. A., and Kropinski, A. M. 1990. High efficiency electroporation of Pseudomonas aeruginosa using frozen cell suspensions. FEMS (Fed. Eur. Microbiol. Soc.) Microbiol. Lett. 58:221-225.

Fürste, J. P., Pansegrau, W., Franck, R., Blöcker, H., Scholz, P., Bagdasarian, M., and Lanka, E. 1986. Molecular cloning of the plasmid RP4 primase region in a multi-host-range tac $\mathrm{P}$ expression vector. Gene 48:119-131.

Gaffney, T. D., Lam, S. T., Ligon, J., Gates, K., Frazelle, A., Di Maio, J., Hill, S., Goodwin, S., Torkewitz, N., Allshouse, A. M., Kempf, H.-J., and Becker, J. O. 1994. Global regulation of expression of antifungal factors by a Pseudomonas fluorescens biological control strain. Mol. Plant-Microbe Interact. 7:455-463.

Galperin, M. Y., Nikolskaya, A. N., and Koonin, E. V. 2001. Novel domains of the prokaryotic two-component signal transduction systems FEMS (Fed. Eur. Microbiol. Soc.) Microbiol. Lett. 203:11-21. 
Haas, D., Blumer, C., and Keel, C. 2000. Biocontrol ability of fluorescent pseudomonads genetically dissected: importance of positive feedback regulation. Curr. Opin. Biotechnol. 11:290-297.

Haas, D., Keel, C., and Reimmann, C. 2002. Signal transduction in plantbeneficial rhizobacteria with biocontrol properties. Antonie Leeuwenhoek 81:385-395.

Hammer, B. K., Tateda, E. S., and Swanson, M. S. 2002. A two-component regulator induces the transmission phenotype of stationary-phase Legionella pneumophila. Mol. Microbiol. 44:107-118.

Heath, J. D., Charles, T. C., and Nester, E. W. 1995. Ti plasmid and chromosomally encoded two-component systems important in plant cell transformation by Agrobacterium species. Pages 67-89 in: Two-Component Signal Transduction. J. A. Hoch and T. J. Silhavy, eds. American Society for Microbiology Press, Washington, D.C.

Heeb, S., Blumer, C., and Haas, D. 2002. Regulatory RNA as mediator in GacA/RsmA-dependent global control of exoproduct formation in Pseudomonas fluorescens CHA0. J. Bacteriol. 184:1046-1056.

Heeb, S., and Haas, D. 2001. Regulatory roles of the GacS/GacA twocomponent system in plant-associated and other gram-negative bacteria. Mol. Plant-Microbe Interact. 14:1351-1363.

Heeb, S., Itoh, Y., Nishijyo, T., Schnider, U., Keel, C., Wade, J., Walsh, U., O'Gara, F., and Haas, D. 2000. Small, stable shuttle vectors based on the minimal pVS1 replicon for use in gram-negative, plant-associated bacteria. Mol. Plant-Microbe Interact. 13:232-237.

Højberg, O., Schnider, U., Winteler, H. V., Sørensen, J., and Haas, D. 1999. Oxygen-sensing reporter strain of Pseudomonas fluorescens for monitoring the distribution of low-oxygen habitats in soil. Appl. Environ. Microbiol. 65:4085-4093.

Hrabak, E. M., and Willis, D. K. 1992. The lemA gene required for pathogenicity of Pseudomonas syringae pv. syringae on bean is a member of a family of two-component regulators. J. Bacteriol. 174:3011-3020.

Hyytiäinen, H., Montesano, M., and Palva. E. T. 2001. Global regulators ExpA (GacA) and KdgR modulate extracellular enzyme gene expression through the RsmA-rsmB system in Erwinia carotovora subsp. carotovora. Mol. Plant-Microbe Interact. 14:931-938.

Keel, C., and Défago, G. 1997. Interactions between beneficial soil bacteria and root pathogens: mechanisms and ecological impact. Pages 27 46 in: Multitrophic Interactions in Terrestrial Systems. A. C. Gange and V. K. Brown, eds. Blackwell Science, London.

Keel, C., Schnider, U., Maurhofer, M., Voisard, C., Laville, J., Burger, U., Wirthner, P., Haas, D., and Défago, G. 1992. Suppression of root diseases by Pseudomonas fluorescens CHA0: importance of the bacterial secondary metabolite 2,4-diacetylphloroglucinol. Mol. Plant-Microbe Interact. 5:4-13.

Kinscherf, T. G., and Willis, D. K. 1999. Swarming in Pseudomonas syringae $\mathrm{B} 728$ a requires gacS (lemA) and gacA but not the acyl-homoserine lactone biosynthetic gene ahlI. J. Bacteriol. 181:4133-4136.

Koch, B., Jensen, L. E., and Nybroe, O. 2001. A panel of Tn7-based vectors for insertion of the $g f p$ marker gene or for delivery of cloned DNA into Gram-negative bacteria at a neutral chromosomal site. J. Microbiol. Methods 45:187-195.

Kwon, O., Georgellis, D., and Lin, E. C. C. 2000. Phosphorelay as the sole physiological route of signal transmission by the Arc two-component system of Escherichia coli. J. Bacteriol. 182:3858-3862.

Labes, M., Pühler, A., and Simon, R. 1990. A new family of RSF1010-derived expression and lac-fusion broad-host-range vectors for gramnegative bacteria. Gene 89:37-46.

Laville, J., Blumer, C., von Schroetter, C., Gaia, V., Défago, G., Keel, C., and Haas, D. 1998. Characterization of the hcnABC gene cluster encoding hydrogen cyanide synthase and anaerobic regulation by ANR in the strictly aerobic biocontrol agent Pseudomonas fluorescens CHA0. J. Bacteriol. 180:3187-3196.

Laville, J., Voisard, C., Keel, C., Maurhofer, M., Défago, G., and Haas, D. 1992. Global control in Pseudomonas fluorescens mediating antibiotic synthesis and suppression of black root rot of tobacco. Proc. Natl. Acad. Sci. U.S.A. 89:1562-1566

Ligon, J. M., Hill, D. S., Hammer, P. E., Torkewitz, N. R., Hofmann, D., and Kempf, H.-J. 1999. Genetic modifications of Pseudomonas that enhance biological disease control. Acta Hortic. 504:53-60.

Maurhofer, M., Keel, C., Haas, D., and Défago, G. 1995. Influence of plant species on disease suppression by Pseudomonas fluorescens strain CHA0 with enhanced antibiotic production. Plant Pathol. 44:4050.

Maurhofer, M., Keel, C., Schnider, U., Voisard, C., Haas, D., and Défago, G. 1992. Influence of enhanced antibiotic production in Pseudomonas fluorescens strain CHA0 on its disease suppressive capacity. Phytopathology 82:190-195.

Paulitz, T. C. 2000. Population dynamics of biocontrol agents and pathogens in soils and rhizospheres. Eur. J. Plant Pathol. 106:401-413.

Pernestig, A.-K., Melefors, Ö., and Georgellis, D. 2001. Identification of
UvrY as the cognate response regulator for the BarA sensor kinase in Escherichia coli. J. Biol. Chem. 276:225-231.

Perraud, A.-L., Weiss, V., and Gross, R. 1999. Signalling pathways in two-component phosphorelay systems. Trends Microbiol. 7:115-120.

Pessi, G., and Haas, D. 2000. Transcriptional control of the hydrogen cyanide biosynthetic genes $h c n A B C$ by the anaerobic regulator ANR and the quorum-sensing regulators LasR and RhlR in Pseudomonas aeruginosa. J. Bacteriol. 182:6940-6949.

Pessi, G., and Haas, D. 2001. Dual control of hydrogen cyanide biosynthesis by the global activator GacA in Pseudomonas aeruginosa PAO1. FEMS (Fed. Eur. Microbiol. Soc.) Microbiol. Lett. 200:73-78.

Pierson, L. S., Wood, D. W., and Pierson, E. A. 1998. Homoserine lactone-mediated gene regulation in plant-associated bacteria. Annu. Rev. Phytopathol. 36:207-225.

Prentki, P., and Krisch, H. M. 1984. In vitro insertional mutagenesis with a selectable DNA fragment. Gene 29:303-313.

Raaijmakers, J. M., Leeman, M., van Oorschot, M. M. P., van der Sluis, I., Schippers, B., and Bakker, P. A. H. M. 1995. Dose-response relationships in biological control of Fusarium wilt of radish by Pseudomonas spp. Phytopathology 85:1075-1081.

Reimmann, C., Beyeler, M., Latifi, A., Winteler, H. V., Foglino, M., Lazdunski, A., and Haas, D. 1997. The global activator GacA of Pseudomonas aeruginosa PAO positively controls the production of the autoinducer $\mathrm{N}$-butyryl-homoserine lactone and the formation of the virulence factors pyocyanin, cyanide, and lipase. Mol. Microbiol. 24:309-319.

Rich, J. J., Kinscherf, T. G., Kitten, T., and Willis, D. K. 1994. Genetic evidence that the gacA gene encodes the cognate response regulator for the lemA sensor in Pseudomonas syringae. J. Bacteriol. 176:74687475 .

Romeo, T. 1998. Global regulation by the small RNA-binding protein CsrA and the non-coding RNA molecule CsrB. Mol. Microbiol. 29:1321-1330

Sacherer, P., Défago, G., and Haas, D. 1994. Extracellular protease and phospholipase $\mathrm{C}$ are controlled by the global regulatory gene gacA in the biocontrol strain Pseudomonas fluorescens CHA0. FEMS (Fed. Eur. Microbiol. Soc.) Microbiol. Lett. 116:155-160.

Sánchez-Contreras, M., Martin, M., Villacieros, M., O’Gara, F., Bonilla, I., and Rivilla, R. 2002. Phenotypic selection and phase variation occur during alfalfa root colonization by Pseudomonas fluorescens F113. J. Bacteriol. 184:1587-1596.

Sambrook, J., Fritsch, E. F., and Maniatis, T. 1989. Molecular Cloning: A Laboratory Manual, 2nd ed. Cold Spring Harbor Laboratory Press, Cold Spring Harbor, NY, U.S.A.

Schmidli-Sacherer, P., Keel, C., and Défago, G. 1997. The global regulator GacA of Pseudomonas fluorescens CHA0 is required for suppression of root diseases in dicotyledons but not in Graminae. Plant Pathol. 46:80-90

Schnider, U., Keel, C., Blumer, C., Troxler, J., Défago, G., and Haas, D. 1995. Amplification of the housekeeping sigma factor in Pseudomonas fluorescens $\mathrm{CHA} 0$ enhances antibiotic production and improves biocontrol abilities. J. Bacteriol. 177:5387-5392.

Schnider-Keel, U., Seematter, A., Maurhofer, M., Blumer, C., Duffy, B., Gigot-Bonnefoy, C., Reimmann, C., Notz, R., Défago, G., Haas, D., and Keel, C. 2000. Autoinduction of 2,4-diacetylphloroglucinol biosynthesis in the biocontrol agent Pseudomonas fluorescens CHA0 and repression by the bacterial metabolites salicylate and pyoluteorin. J. Bacteriol. 182:1215-1225

Stanisich, V. A., and Holloway, B. W. 1972. A mutant sex factor of Pseudomonas aeruginosa. Genet. Res. 19:91-108.

Suzuki, K., Wang, X., Weilbacher, T., Pernestig, A.-K., Melefors, Ö. Georgellis, D., Babitzke, P., and Romeo, T. 2002. Regulatory circuitry of the CsrA/CsrB and BarA/UvrY systems of Escherichia coli. J. Bacteriol. 184:5130-5140.

Tao, W., Deschenes, R. J., and Fassler, J. S. 1999. Intracellular glycerol levels modulate the activity of $S \ln 1 \mathrm{p}$, a Saccharomyces cerevisiae twocomponent regulator. J. Biol. Chem. 274: 360-367.

Thomashow, L. S. 1996. Biological control of plant root pathogens. Curr Opin. Biotechnol. 7:343-347.

Toyoda-Yamamoto, A., Shimoda, N., and Machida, Y. 2000. Genetic analysis of the signal-sensing region of the histidine protein kinase VirA of Agrobacterium tumefaciens. Mol. Gen. Genet. 263:939-947.

Uhl, M. A., and Miller, J. F. 1996. Integration of multiple domains in a two-component sensor protein: the Bordetella pertussis BvgAS phosphorelay. EMBO (Eur. Mol. Biol. Organ.) J. 15:1028-1036.

Vieira, J., and Messing, J. 1991. New pUC-derived cloning vectors with different selectable markers and DNA replication origins. Gene 100:189-194

Voisard, C., Bull, C., Keel, C., Laville, J., Maurhofer, M., Schnider, U., Défago, G., and Haas, D. 1994. Biocontrol of root diseases by Pseudo- 
monas fluorescens CHA0: current concepts and experimental approaches. Pages 67-89 in: In Molecular Ecology of Rhizosphere Microorganisms. F. O'Gara, D. Dowling, and B. Boesten, eds. VCH, Weinheim.

Voisard, C., Keel, C., Haas, D., and Défago, G. 1989. Cyanide production by Pseudomonas fluorescens helps suppress black root rot of tobacco under gnotobiotic conditions. EMBO (Eur. Mol. Biol. Organ.) J. 8:351-358.

Walsh, U. F., Morissey, J. P., and O'Gara, F. 2001. Pseudomonas for biocontrol of phytopathogens: from functional genomics to commercial exploitation. Curr. Opin. Biotechnol. 12:289-295.
Whistler, C. A., Corbell, N. A., Sarniguet, A., Ream, W., and Loper, J. E. 1998. The two-component regulators GacS and GacA influence accumulation of the stationary-phase sigma factor $\sigma^{\mathrm{s}}$ and the stress response in Pseudomonas fluorescens Pf-5. J. Bacteriol. 180:6635-6641.

Whiteley, M., Lee, K. M., and Greenberg, E. P. 1999. Identification of genes controlled by quorum sensing in Pseudomonas aeruginosa. Proc. Natl. Acad. Sci. U.S.A. 96:13904-13909.

Williams, S. B., and Stewart, V. 1999. Functional similarities among twocomponent sensors and methyl-accepting chemotaxis proteins suggest a role for linker region amphipathic helices in transmembrane signal transduction. Mol. Microbiol. 33:1093-1102. 